\title{
Inovasi Kebijakan dalam Perspektif Administrasi Publik Menuju Terwujudnya Good Public Policy Governance
}

\section{Innovation of Policy in Public Administration Perspective toward the realization of Good Public Policy Governance}

\author{
Ahmad Sururi \\ Program Studi Administrasi Negara Fakultas Ilmu Sosial dan Politik \\ Universitas Serang Raya \\ ahmadbroer@gmail.com
}

\begin{abstract}
Abstrak
Kebijakan publik sebagai instrumen yang mensinergikan peran pemerintah dan publik belum berjalan secara optimal. Terjadinya fenomena beberapa kebijakan yang dibatalkan atau direvisi oleh Pemerintah merupakan indikasi masih adanya tumpang tindih kebijakan dan rendahnya kemampuan berinovasi (ability to innovate) dan kemauan berinovasi (willingnes to inovate) pejabat publik. Untuk itu diperlukan inovasi kebijakan yang secara substantif dapat memberikan penguatan dalam menyelesaikan permasalahan ditengah masyarakat. Tujuan dalam penelitian ini adalah untuk mendeskripsikan dan melakukan analisis bagaimana inovasi kebijakan dalam perspektif pendekatan administrasi pubik dan menganalisis inovasi kebijakan menuju terwujudnya good public policy governance. Metode yang digunakan adalah pendekatan kualitatif. Teknik yang dilakukan adalah survei literatur akademis di bidang keilmuan kebijakan publik guna memperoleh konsep-konsep yang relevan dengan kajian inovasi kebijakan publik. Teknik pengumpulan data melalui penelusuran berbagai sumber dan literatur baik dari dokumen pemerintah maupun pemberitaan media massa cetak dan elektronik, jurnal dan buku-buku yang terkait dengan administrasi pubik dan inovasi kebijakan. Penerapan prinsip-prinsip inovasi melalui NPS adalah representasi dari penerapan inovasi kebijakan. Publik dipandang secara utuh, manusiawi dan humanis melalui pendekatan yang memberikan space kepada publik untuk berkolaborasi dan berorientasi pada peningkatan kinerja. Good public policy governance akan terwujud melalui pendekatan 1) Jenis dukungan; 2) Manajemen Inovasi; 3) Karakteristik dalam penerapan nilai.
\end{abstract}

Kata Kunci : Inovasi Kebijakan, Administrasi Publik, Good Pubic Policy Governance

\begin{abstract}
Public policy, as an instrument of synergizing the role of government and public, has not run optimally. A phenomenon in which some policies are cancelled or revised by government indicates overlapping policy and low ability to innovate and willingness to innovate public officers. For that reason, a policy innovation that can give reinforcement substantively in solving problem amid society is required. The objective of research was to describe and to
\end{abstract}


analyze the policy innovation in public administration approach and the policy innovation toward the good public policy governance. The method employed was qualitative approach one. The technique conducted was academic literature survey on public policy science in order to acquire concepts relevant to public policy innovation study. Data was collected through investigating various sources and literatures from government document, and printed and electronic media broadcasting, journals and books related to public administration and policy innovation. The application of innovation principles through NPS is the representation of policy innovation application. Public is viewed comprehensively, humanely and humanistically through an approach giving the public the space to collaborate and to be oriented to performance improvement. Good public policy governance will be realized through 1) support type; 2) innovation management; 3) characteristics in value application.

\section{Keywords: Policy Innovation, Public Administration, Good Pubic Policy Governance}

\section{A. Pendahuluan}

Sebagai sebuah pilihan rasional, inovasi seakan sudah menjadi bagian yang tidak terpisahkan dan menjadi tuntutan organisasi publik baik di Pemerintah Pusat maupun daerah. Hal tersebut seiring dengan berbagai perubahan dan dinamika tuntutan masyarakat. Inovasi diharapkan dapat menjadi strategi dalam meningkatkan daya ungkit kinerja organisasi baik dalam memproduksi produk maupun jasa. Salah satu upaya srategis organisasi publik untuk dapat terus melakukan perubahan tersebut adalah dengan menciptakan produk baru (baik dalam arti barang maupun jasa), struktur baru, hubungan baru dan kultur baru (Siagian, 2007 : 58). Dengan demikian, terdapat sebuah konsekuensi logis bagi organisasi publik sebagai entitas pelayanan publik yaitu diterapkannya prinsip pelayanan dengan berbasis indikator efektif, efisien dan produktif serta tidak lagi menerapkan prinsip-prinsip yang "asal terlayani" kepada publik.

Tuntutan inovasi dalam organisasi publik dan pemerintah pusat serta daerah memerlukan perhatian yang lebih serius dan harus dilakukan secara terintegratif dan simultan. Hal ini disebabkan karena inovasi yang dilakukan secara terintegratif dan simultan memiliki daya sebar yang berpengaruh terhadap seluruh bagian dalam organisasi. Inovasi yang dilakukan secara parsial hanya akan berpengaruh terhadap bagian tertentu dalam organisasi dan kurang memberikan efek dan impact factor terhadap visi dan misi organisasi.

Di Indonesia penerapan regulasi tentang inovasi terdapat dalam Undang-undang Nomor 23 Tahun 2014. Disebutkan inovasi daerah diperlukan dalam rangka peningkatan kinerja penyelenggaraan Pemerintahan Daerah, Pemerintah Daerah dapat melakukan inovasi. Inovasi adalah 
semua bentuk pembaharuan dalam penyelenggaraan Pemerintahan Daerah. Inisiatif inovasi dapat berasal dari kepala daerah, anggota DPRD, aparatur sipil negara, Perangkat Daerah, dan anggota masyarakat.

Tri Widodo Utomo (2016) mengatakan meskipun inovasi di Indonesia sudah berkembang pesat akan tetapi masih dilakukan secara relatif parsial, piecemeal dan stagnan. Parsial karena biasanya sebuah inovasi tidak otomatis terkoneksi dengan inovasi lain. Tidak terkoneksi dengan peta jalan (road map) organisasi, serta tidak memiliki visi jangka panjang. Sementara itu, sifat 'piecemeal' (satu per satu) inovasi mereka karena kurang memberi efek besar dan kolektif. Akibatnya, inovasi "tidak pergi ke manamana" alias stagnan. Bahkan, rencana pembangunan lima tahunan baru mengindikasikan program sasaran strategis, namun belum mengakomodir kebutuhan inovasi. Oleh sebab itu sebuah inovasi dalam organsiasi pubik memerlukan daya kolaborasi dan elaborasi yang bersifat enable.

Pada level pemerintahan baik pemerintah daerah maupun pusat, kemampuan berinovasi teutama inovasi kebijakan merupakan bagian dari kemampuan dalam memanfaatkan potensi sumber daya baik lokal maupun nasional dengan didukung kreativitas birokrasi di berbagai tingkatan.
Kebijakan pemerintah untuk mendukung kegiatan inovasi juga mutlak diperlukan (Bank Dunia, 2010 dalam Firdausy, 2013) menekankan pentingnya peran pemerintah tidak hanya sebatas penyediaan dana, institusi pendidikan dan penelitian serta laboratorium untuk inovasi maupun fasilitas fisik lainnya, melainkan juga dalam penetapan atau perubahan peraturan, kebijakan fiskal (pajak, subsidi dan pinjaman) dan moneter (kredit dan suku bunga), serta kebijakan investasi dan perdagangan maupun insentif dan disinsentif lainnya. Tugas pemerintah dalam mendukung kegiatan inovasi tersebut di atas memang perlu, walaupun dalam penerapannya tidak mudah dilakukan. Seperti telah diuraikan sebelumnya bahwa inovasi harus memiliki impact factor (faktor dampak). Dalam konteks tersebut, inovasi kebijakan bertujuan meningkatkan daya saing, dampak dan manfaat bagi kepentingan publik. Oleh sebab itu pola sinergi kebijakan baik dari konsep formulasi, implementasi dan evaluasi antara pemerintah pusat dan daerah merupakan bagian yang tidak terpisahkan. Bentuk konkrit sinergi itu salah satunya dengan merombak regulasi yang dianggap penghambat (Sayekti, 2016).

Inovasi kebijakan menjadi tidak bersifat inovatif apabila kebijakan tersebut tidak mendorong dampak daya saing dan memberikan manfaat bagi kepentingan publik. Salah satu prasyarat penting untuk mendorong tumbuhnya inovasi kebijakan 
adalah kreatifitas birokrasi dalam menciptakan daya perubahan dan gagasan-gagasan baru. Kebijakan memiliki beberapa perbedaan yang cukup mendasar. Pertama, sebuah kebijakan pada umumnya meniadakan kebijakan yang lama, atau bersifat kontradiktif dan yang kedua, kebijakan dan inovasi berbeda dalam hal degree of creativity. Sekali ditetapkan, maka kebijakan kehilangan sebagian besar aspek kreativitasnya. (Tri Widodo Utomo, 2016)

Hal-hal yang mendasari pentingnya inovasi kebijakan dapat dilihat dari fenomena beberapa peraturan daerah yang dicabut atau direvisi beberapa waktu yang lalu oleh Pemerintah melalui Mendagri Cahyo Kumolo, 3.143 Peraturan Daerah (Perda) atau Peraturan Kepala Daerah (Perkada) yang dicabut atau direvisi oleh pemerintah. Mayoritas Perda yang dicabut terkait investasi dan perijinan. Secara rinci, dari 3.143 Perda yang dicabut atau direvisi itu sebanyak 1.765 adalah perda atau perkada kabupaten/ kota yang dicabut atau direvisi Mendagri. Kemudian 111 peraturan atau putusan Mendagri yang dicabut atau revisi oleh Mendagri dan 1.267 perda atau perkada kabupaten/kota yang dicabut atau direvisi Gubernur (https://news. detik.com/berita).

Penyusunan kebijakan yang asal-asalan dan tidak melalui proses perumusan yang tepat menjadi penyebab dicabutnya Perda/Perkada tersebut. Selain itu lemahnya fungsi intervensi evaluatif dan controlling dari pemerintah pusat terhadap pemerintah daerah pada saat penyusun kebijakan daerah tersebut. Inovasi kebijakan publik menjadi keharusan ketika kebijakan manual yang hanya berfungsi sekedar menggugurkan kewajiban pemerintah melahirkan berbagai kekecewaan dan kecemasan ditengah-tengah publik, khususnya yang menyangkut kepentingan hajat hidup orang banyak (Dede Mariana, 2010).

Sejalan dengan diterapkannya otonomi daerah yang memberikan kewenangan bagi pemerintah daerah untuk menyusun kebijakan, maka peran pejabat publik di daerah dalam melakukan inovasi kebijakan publik diharapkan akan semakin meningkat dan memberikan dampak yang positif bagi kualitas kebijakan atau peraturan yang akan disusun. Dengan demikian kualitas peraturan daerah menjadi indikator penting kinerja tata pemerintahan di daerah (Agus Dwiyanto, 2010:10). Rendahnya kemampuan berinovasi (ability to innovate) dan kemauan berinovasi (willingnes to inovate) menjadi tantangan bagi kalangan pejabat publik di instansi pemerintah baik di daerah maupun pusat. Di sisi lain kebijakan publik sebagai instrumen yang berfungsi menyatukan pemerintah dan publik belum berjalan secara optimal, hal ini disebabkan masih terdapat tumpang tindih kebijakan yang dikeluarkan oleh instansi pembuat kebijakan yang berbeda. Contoh dari kegagalan kebijakan 
pelayanan publik di Indonesia dalam wujud adanya diskonektivitas dari output kegiatan Kementerian dan Lembaga NonKementerian, sebagai misal, beberapa waduk yang sudah dibangun oleh pemerintah tidak dapat berfungsi karena tidak ada saluran irigasi, pelabuhan tidak dapat beroperasi secara wajar karena tidak ada jalan yang menghubungkannya dengan kawasan industri (Agus Dwiyanto, 2016). Untuk menghindari terminasi kebijakan tersebut, maka perlu adanya reorientasi kebijakan dari setiap dinas atau instansi yang lebih terfokus baik dalam hal proses, metode maupun produk setiap kebijakan publik yang dihasilkan.

Permasalahan-permasalahan seperti disparitas pembangunan karena kurang tepatnya analisis kebijakan, perilaku koruptif para pejabat publik karena lemahnya regulasi, persoalan kebijakan ketahanan pangan yang tumpang tindih, persoalan kebijakan kemiskinan, kesehatan dan pengangguran serta tingkat pendidikan masyarakat yang rendah merupakan beberapa contoh kegagalan kebijakan publik dalam merespon dan menyelesaikan problematika publik.

Inovasi kebijakan publik secara substantif dapat memberikan penguatan dalam menyelesaikan masalah yang terjadi ditengah masyarakat. Meskipun inovasi kebijakan dilakukan tidak mengikuti tren atau secara musiman akan tetapi inovasi kebijakan dapat menjadi keputusan alternatif dalam dimensi kebijakan publik di masa kini dan masa yang akan datang. Innovation policies and innovations in public sector activities are oriented to address market failures and in particular (Alvarez et al., 2012). artinya inovasi kebijakan dan inovasi sektor publik berorientasi mengatasi kegagalan pasar dan seluruh bagian yang terdapat didalamnya. Adapun alasan perlunya inovasi dalam suatu organisasi publik yaitu :

1. Size of the public sector: The public sector has an impact on many countries in the percentage of GDP. Innovation in the public sector can affect the overall productivity growth by reducing the cost of inputs, and increasing the value of products through better organization.

2. A need for the policy to match the evolution of the economies in a globalized context.

3. The public sector establishes the rules for private sector innovation.

Besarnya kepentingan sektor publik memiliki dampak pada suatu negara terutama dalam persentase PDB. Disisi lain inovasi di sektor publik dapat secara keseluruhan berpengaruh terhadap pertumbuhan produktivitas, meningkatkan nilai produk melalui perbaikan organisasi, kebutuhan akan kebijakan yang sesuai dengan perkembangan ekonomi di era global, dan inovasi sektor publik akan menjamin inovasi sektor swasta. 


\section{B. Landasan Teoritis}

United Nations Departement of Economic And Social Affairs (2006) memberikan analisis tentang inovasi sebagai bagian dari revitalisasi administrasi publik, adanya Inovasi dan eksperimen di pemerintah pusat dan daerah khususnya di bidang pelayanan dan pada saat ini berlangsung di berbagai penjuru dunia sebagai bagian dari upaya pemerintah untuk merevitalisasi administrasi publik. Pertukaran dan berbagi pengalaman inovatif ini dapat menciptakan "pengetahuan baru" yang dapat diakses oleh negara-negara di seluruh dunia.(http://www.unpan.org/innovme.

Dalam perspektif sektor publik, inovasi memunculkan kebijakan baru dalam mengatasi masalah-masalah kebijakan publik. Seperti dikatakan dalam United Nations Departemen of Economic and Social Affairs (2006) sebagai berikut : "Public sector management innovation may also be defined as the development of new policy designs and new standard operating procedures by public organizations to address public policy problems. Thus, an innovation in public administration is an effective, creative and unique answer to new problems or a new ans wer to old problems". Inovasi manajemen sektor publik juga dapat didefinisikan sebagai pengembangan rancangan kebijakan baru dan prosedur operasi standar baru oleh organisasi publik untuk mengatasi masalah kebijakan publik. Dengan demikian, sebuah inovasi dalam administrasi publik adalah jawaban yang efektif, kreatif dan unik terhadap masalah baru atau masalah baru terhadap masalah lama. Selanjutnya, sebuah inovasi bukanlah solusi yang tertutup dan lengkap, namun merupakan solusi terbuka, ditransformasikan oleh mereka yang mengadopsinya. Secara konseptual terdapat tiga jenis inovasi kebijakan, yaitu :

1. Policy innovation: new policy direction and initiatives (inovasi kebijakan). Inovasi kebijakan yang dimaksud adalah adanya inisiatif dan arah kebijakan baru. Ini berarti bahwa setiap kebijakan (publik) yang dikeluarkan pada prinsipnya harus memuat sesuatu yang baru.

2. Innovations in the policy-making process (inovasi dalam proses pembuatan kebijakan). Pada peranan ini, maka fokusnya adalah pada inovasi yang mempengaruhi proses pembuatan atau perumusan kebijakan.

3. Policy to foster innovation and its diffusion. Kebijakan yang dimaksud adalah kebijakan yang khusus diciptakan untuk mendorong dan mengembangkan, dan menyebarkan inovasi di berbagai sektor. (Albury, 2003)

Secara khusus inovasi kebijakan menurut Walker (Tyran \& Sausgruber, 2003:4), policy innovation is a policy which is new to the states adopting it, no matter 
how old the program may be or how many other states may have adopted it. Jadi yang dimaksud dengan inovasi kebijakan menurut Walker adalah sebuah kebijakan yang baru bagi negara yang mengadopsinya, tanpa melihat seberapa usang programnya atau seberapa banyak negara lain yang telah mengadopsi sebelumnya. Dalam penelitiannya, Benyamin Abdurahman (2014) mengemukakan pertanyaan tentang ada apa dengan regulasi dan kebijakan kerja sama daerah selama ini? Produk hukum dan kebijakan pasca reformasi memberikan berbagai pembelajaran pembangunan daerah dan sekaligus menyisakan masalah yang belum terselesaikan. Melekat dengan pembangunan daerah, timbul berbagai implikasi pelaksanaan otda, seperti kegagalan daerah otonom baru, meruncingnya gesekan 'kepentingan antar daerah' (baca: ego daerah), permasalahan ego sektoral, miskoordinasi, hingga mismanagement (salah urus) di daerah. Pada sisi lain, inovasi daerah dalam rangka menyiasati dan meredam berbagai implikasi otonomi daerah melalui berbagai bentuk (aliansi) kerja sama antar daerah kewilayahan secara dramatis 'terbonsai' dalam bingkai regulasi dan kebijakan. Kondisi tersebut terjadi karena kelemahan pada konsep dasar yang ambivalen, dan misleading terhadap esensi dari pengembangan serta pembangunan wilayah itu sendiri. Kemudian Wijayanti (2012) dalam penelitiannya tentang implementasi inovasi kebijakan pembangunan berkelanjutan menyimpulkan bahwa keberhasilan inovasi kebijakan tercipta karena berbagai faktor yaitu :

1. Inisiatif dan komitmen Walikota

2. Perubahan mindset sehingga terbangun kepercayaan dalam pengelolaan PKL

3. Reformasi birokrasi yang diikuti penyusunan dokumen pendukung

4. Mekanisme implementasi yang berkesinambungan dan terintegrasi

5. Pangkas anggaran dan fokus untuk pemanfaatan yang berdampak terutama kesejahteraan.

Penelitian yang dilakukan oleh Elanor D Glor (2003) menyimpulkan bahwa keberhasilan penerapan proses inovatif untuk memperbaiki tata kelola pemerintahan, kinerja administrasi publik dan untuk mengatasi persoalan publik secara efektif. Agar efektif publik dan pemerintah harus terlebih dahulu berkomitmen untuk mengatasinya. Mereka juga harus mengidentifikasi strategi dan teknik yang efektif untuk melakukannya, dan menciptakan mekanisme untuk mengembangkan keterampilan dan nilai-nilai dalam mewujudkannya. Sedangkan Mirlinda Batalli (2011) dalam penelitiannya menyimpulkan proses inovasi administrasi publik bertujuan untuk memodernisasi kapasitas administrasi dan menciptakan pemerintahan yang lebih efisien dan akuntabel. Inovasi juga mempengaruhi perbaikan manajemen 
publik, implementasi kebijakan publik dan mendorong pertumbuhan ekonomi. Oleh karena itu, peran Negara menjadi lebih sebagai "pelayan" daripada "penguasa". Dalam perspektif administrasi publik, dikenal tiga paradigma yaitu : Old Public Administration, New Public Administration, New Public Manajemen dan New Public Services. Tabel 1 diuraikan pandangan keempat paradigma tersebut tentang inovasi :

Tabel 1

Paradigma Administrasi Publik

\begin{tabular}{|c|c|c|c|c|}
\hline & OPA & NPA & NPM & NPS \\
\hline $\begin{array}{c}\text { Arti } \\
\text { Penting } \\
\text { Inovasi }\end{array}$ & $\begin{array}{l}\text { Kurang } \\
\text { penting }\end{array}$ & Penting & Penting & $\begin{array}{l}\text { Sangat } \\
\text { penting }\end{array}$ \\
\hline $\begin{array}{l}\text { Ranah } \\
\text { inovasi }\end{array}$ & $\begin{array}{c}\text { Integral } \\
\text { organisasi }\end{array}$ & $\begin{array}{c}\text { Praktik- } \\
\text { praktik } \\
\text { administra- } \\
\text { si publik } \\
\text { yang lebih } \\
\text { adil dan } \\
\text { mampu } \\
\text { menyelesai } \\
\text { kan } \\
\text { masalah } \\
\text { publik }\end{array}$ & $\begin{array}{c}\text { Hubungan } \\
\text { organisasi } \\
\text { publik- } \\
\text { pelanggan }\end{array}$ & $\begin{array}{c}\text { Holistik } \\
\text { dan } \\
\text { integral }\end{array}$ \\
\hline $\begin{array}{l}\text { Tujuan } \\
\text { inovasi }\end{array}$ & $\begin{array}{c}\text { Menjalank } \\
\text { an sistem } \\
\text { dan aturan } \\
\text { secara } \\
\text { efektif }\end{array}$ & $\begin{array}{c}\text { Menjalank } \\
\text { an sistem } \\
\text { administras } \\
\text { i yang } \\
\text { sadar akan } \\
\text { nilai dan } \\
\text { norma } \\
\end{array}$ & $\begin{array}{l}\text { Meningkat } \\
\text { kan } \\
\text { produktivit } \\
\text { as dan } \\
\text { efisiensi } \\
\text { kerja }\end{array}$ & $\begin{array}{l}\text { Memenu } \\
\text { hi } \\
\text { kepentin } \\
\text { gan } \\
\text { publik }\end{array}$ \\
\hline
\end{tabular}

Dari keempat paradigma administrasi publik di atas, maka paradigma New Public Services (NPS) merupakan representasi dari inovasi kebijakan publik. Penerapan prinsip-prinsip inovasi melalui NPS, publik dipandang secara utuh dan humanis, tidak direduksi sebagai pelanggan yang berciri ekonomistis- egoistis maupun sebagai pihak luar yang menjadi sasaran mekanis birokrasi.

Selanjutnya disebutkan bahwa paradigma NPS juga menaruh perhatian yang besar terhadap inovasi dan bersifat integral serta komprehensif karena NPS merupakan pendekatan yang memberikan nilai tinggi pada kolaborasi antar pihak dan peningkatan kinerja setiap elemen organisasi. NPS memandang arti penting inovasi kebijakan secara holistik dan integral dan bertujuan untuk mematuhi kepentingan publik.

Vigoda-Gadot, et al (2005:70) menganalisis bagamana keterkaitan inovasi dan pemikiran administrasi publik. Selanjutnya Vigoda-Gadot, et al (2005) membagi tiga perspektif evolusi perkembangan pemikiran administrasi publik yakni (1) classic public administration canon; (2) new public management doctrine; dan (3) postmanagerial avenues.

Selanjutnya Jean Hartley (2005:29) mendeskripsikan perbedaan inovasi, improvement, Role of Policy makers dan role of public managers dan role of the population dalam konsep pendekatan administrasi publik pemerintahan. Disebutkan Hartley bahwa "Innovation is an issue of considerable significance for both public and private sector organizations. Although the sceptical view of the public sector is that it is resistant to significant innovation, there have been 
numerous and significant examples". Inovasi adalah isu yang sangat penting bagi organisasi sektor publik dan swasta. Meskipun terdapat pandangan yang skeptis terhadap sektor publik agar dapat bertahan terhadap inovasi.

United Nations Departemen of Economic and Social Affairs (2006:6) menganalisis sejumlah prinsip dan strategi utama untuk inovasi dalam pemerintahan sebagai berikut:

1. Mengintegrasikan layananan;

2. Desentralisasi pemberian layanan;

3. Memanfaatkan kemitraan;

4. Melibatkan warga negara; dan

5. Mengambil keuntungan dari Teknologi Informasi dan Komunikasi.

Glor (2001) mengidentifikasi pola inovasi kebijakan berdasarkan tiga pendekatan:

1. Motivasi individu: Ini bisa berupa ekstrinsik atau intrinsik. Motivasi intrinsik muncul dari dalam individu, misalnya, sebuah komitmen terhadap sebuah program karena adanya identifikasi pribadi dengannya. Motivasi ekstrinsik timbul dari. Di luar individu, misalnya, kontrol manajerial atau beberapa bentuk. Hadiah atau insentif dari luar. Motivasi intrinsik memungkinkan tingkat yang lebih tinggi. Mencari masalah dan pemecahan masalah dibandingkan dengan motivasi ekstrinsik
2. Budaya organisasi: Ini bisa berupa budaya bottom-up atau top-down budaya

3. Tantangan: Ini bisa berupa minor (misalnya, berisiko rendah terhadap individu atau organisasi) atau mayor (berisiko tinggi terhadap individu dan organisasi).

Daya penyebaran inovasi kebijakan terjadi dengan merujuk pada dua determinan penting, yaitu internal determinant dan regional difusion. (Tyran, 2003). Yang dimaksud dengan internal determinant atau penentu internal adalah karakteristik sosial, ekonomi, dan politik sebuah negara menentukan keinovatifan sebuah negara. Sedangkan regional diffusion adalah kemungkinan sebuah negara mengadopsi kebijakan tertentu lebih tinggi jika negara-negara tetangganya telah mengadopsi kebijakan tersebut.

Sebuah contoh ilustrasi dari terjadinya internal determinants yang menyebabkan terjadinya inovasi kebijakan adalah perubahan sosial ekonomi dalam negeri, demonstrasi publik, instabilitas politik yang memaksa terjadi perubahan kebijakan mendasar yang berkenaan dengan kepentingan publik. Regional Diffusion terjadi ketika negara tetangga atau negara lain menerapkan kebijakan tertentu yang ditiru oleh kita. Misalnya dalam hal kebijakan di bidang lalu lintas, di Malaysia diberlakukan kewajiban menyalakan lampu bagi pengendara sepeda motor untuk menekan angka 
kecelakaan. Kebijakan ini kemudian ditiru oleh Indonesia, terutama di beberapa kota besar, dengan hasil yang diharapkan dapat menekan angka kecelakaan lalu lintas. (Yoqi Suwarno dalam BSIAN, 2016)

Bagan 1

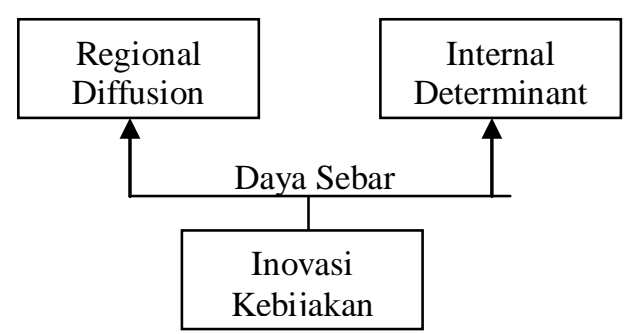

Navvaro (2016) mendefinisikan 3 (tiga) pendekatan kunci prinsip inovasi kebijakan yaitu : 1) creation of interactive value (social and public); 2) distributed co-creation; and 3) mass collaboration to inspire the public sphere (Hilgers and Ihl, 2010),

Tabel 2

Prinsip Inovasi Kebijakan

\begin{tabular}{|l|l|}
\hline Charateristics & \multicolumn{1}{|c|}{ Public Innovation } \\
\hline Support & $\begin{array}{l}\text { Government officials } \\
\text { from all agenicies in } \\
\text { collaboration with non } \\
\text { governmental actors } \\
\text { achieve changes in } \\
\text { organizational } \\
\text { processess through } \\
\text { Creation }\end{array}$ \\
\hline $\begin{array}{l}\text { Management } \\
\text { of Innovation }\end{array}$ & $\begin{array}{l}\text { The reorganization of } \\
\text { the administration is } \\
\text { the product of } \\
\text { collaboration (open } \\
\text { external and internal), } \\
\text { trend corelational }\end{array}$ \\
\hline
\end{tabular}

\begin{tabular}{|l|lr|}
\hline & $\begin{array}{l}\text { organization } \\
\text { horizontal }\end{array}$ \\
\hline $\begin{array}{l}\text { Type of } \\
\text { relationship }\end{array}$ & $\begin{array}{l}\text { The shapes } \\
\text { relationship of } \\
\text { supported by peer } \\
\text { production, }\end{array}$ \\
source, open \\
collaboration \\
crowdsurcing \\
\hline Kind of value \\
creation & $\begin{array}{l}\text { Public value produced } \\
\text { by the collaboration } \\
\text { between governancem } \\
\text { citizen and private } \\
\text { sector }\end{array}$ \\
\hline
\end{tabular}

Tujuan dalam penelitian ini adalah untuk mendeskripsikan dan menganalisis bagaimana inovasi kebijakan dalam perspektif pendekatan administrasi pubik dan menganalisis inovasi kebijakan sebagai upaya menuju terwujudnya good policy governance (tata kelola kebijakan pemerintahan yang baik).

\section{Metode Penelitian}

Metode yang digunakan adalah pendekatan kualitatif. Teknik yang dilakukan oleh peneliti adalah survei literatur akademis di bidang keilmuan kebijakan publik guna memperoleh konsep-konsep yang relevan dengan kajian inovasi kebijakan publik. Teknik pengumpulan data melalui penelusuran berbagai sumber dan literatur baik dari dokumen pemerintah maupun pemberitaan media massa cetak dan elektronik, jurnal dan buku-buku yang terkait dengan administrasi pubik dan 
inovasi kebijakan. Data sekunder tersebut diolah dan dideskripsikan dalam bentuk narasi sesuai dengan kebutuhan data. Selanjutnya dilakukan proses analisis data berdasarkan teori dan konsep dan inovasi kebijakan publik serta selanjutnya dilakukan proses intrepretasi data.

\section{Hasil dan Pembahasan}

\section{a. Inovasi Kebijakan dalam perspektif Administrasi Publik}

Paradigma administrasi publik berdasarkan prinsip-prinsip New Public Services (NPS) merupakan representasi inovasi kebijakan. Prinsip-prinsip NPS tersebut yaitu :

a) Menekankan pada konsep hubungan kepercayaan dan kolaborasi dengan sesama warga negara dan bukan hanya sebagai pelanggan.

b) Kepentingan publik menciptakan kepentingan dan tanggung jawab bersama.

c) Nilai pada pelayanan publik dan komitmen warga negara untuk membuat kontribusi

d) Berpikir strategis, bertindak demokratis

e) Akuntabilitas tidaklah sederhana

f) Mengarahkan dengan membantu warga negara untuk mengartikulasikan dan memenuhi kepentingan bersama

g) Menghargai orang dan tidak hanya fokus pada produktifitas

Administrasi publik mensyaratkan inovasi kebijakan melalui terciptanya pengetahuan-pengetahuan baru dalam bentuk inovasi pelayanan terhadap kepentingan publik. Disinilah titik tekan pentingnya kemampuan inovator dalam menerapkan kemampuan administrator dan skill berbasis teknikal. Dalam perspektif administrasi publik, inovasi kebijakan tidak hanya terfokus pada aspek perencanaan, pengorganisasian, penggerakan dan pengawasan akan tetapi juga terletak pada kemampuan inovator dalam menerapkan ilmu pengetahuan dan teknologi menjadi sebuah inovasi kebijakan.

\section{b. Kriteria Inovasi Kebijakan dalam perspektif Administrasi Publik
a) Inovasi kebijakan berdasarkan proses.

Penerapan inovasi yang dilakukan berdasarkan proses meliputi peningkatan kualitas kerja dari berbagai stakeholder yang dilakukan secara efisien dan efektif. Mekanisme kerja organisasi publik yang cenderung lambat, berbelit-belit dan rumut dirubah ke arah mekanisme kerja yang cepat, tepat dan produktif. Tujuan dari inovasi proses adalah masyarakat mendapatkan pelayanan sesuai dengan standar pelayanan yang diharapkan.

Menurut kajian dari Lembaga Administrasi Negara (2016), terdapat dua jenis inovasi proses kerja. Pertama, inovasi secara internal, yang menyasar proses kerja yang dilakukan di antara pegawai dalam lingkup intern suatu organisasi. Kedua, inovasi secara eksternal yang dilakukan oleh unit kerja 
yang berhubungan secara langsung dengan pihak luar (pelanggan dan pemangku kepentingan) dalam rangka menjalankan proses kerja rutin atau memberikan pelayanan publik. Ruang lingkup dari inovasi proses meliputi standar operasional prosedur (SOP), tata laksana, sistem, dan prosedur. Kriteria penentuan:

1) Inovasi ini dilangsungkan pada level tata laksana rutin.

2) Inovasi disebut sukses apabila proses kerja yang dilakukan menjadi semakin cepat, mudah, dan efektif.

3) Dalam tata laksana rutin, pihak yang berwenang menjadi semakin sedikit dan duplikasi atau tumpang tindih tahapan menjadi hilang.

4) Bagi organisasi yang melakukan pelayanan kepada masyarakat secara langsung, indikator kesuksesan adalah peningkatan kepuasan terhadap pelayanan yang diberikan, yang dapat diukur melalui indeks kepuasan masyarakat (IKM).

\section{b) Inovasi Berdasarkan Metode.}

Penerapan Inovasi metode dilakukan berdasarkan model dan stategi kebijakan yang baru. perubahan metode lama ke arah metode yang baru dimaksudkan agar dapat dicapai tujuan yang lebih optimal. Menurut kajian LAN (2016) Kriteria penentuan berdasarkan metode dilakukan sebagai berikut :

1) Bentuk dari inovasi ini adalah kebijakan organisasi yang menggariskan cara baru dalam melakukan proses kerja organisasi. Cara baru ini dapat menyasar berbagai ranah seperti cara membuat keputusan, cara membuat produk, cara melakukan pelayanan, dan sebagainya.

2) Inovasi ini dilakukan ketika cara atau metode lama yang digunakan organisasi dirasa tidak lagi efektif dan menguntungkan.

3) Mengingat inovasi ini bersifat makro dan dapat diterapkan untuk bidang yang luas, untuk membedakannya dari inovasi yang lain, maka perlu dicari inovasi metode yang sifatnya holistik dan paradigmatis. Metode yang baru tersebut diterapkan untuk seluruh kegiatan dan sektor yang ada di organisasi tersebut.

\section{c) Inovasi kebijakan berdasarkan produk}

Penerapan inovasi berdasarkan produk dilakukan dengan memodifikasi berbagai produk-produk yang dihasilkan oleh organisasi dengan tujuan agar organsisasi mempunyai daya saing. Menurut kajian LAN (2016), kriteria penentuan inovasi produk adalah :

1) Inovasi ini dipakai atau dinikmati secara langsung oleh pelanggan

2) Organisasi terlibat secara langsung, aktif, dan penuh melalui proses internalnya untuk menghasilkan keluaran yang dinikmati pelanggan tersebut.

3) Inovasi produk disebut sukses apabila: produk yang dihasilkan semakin 
bermutu dan meningkat kualitasnya sehingga pemakai semakin puas; atau produk yang diciptakan merupakan produk baru yang tidak ada presedennya. Kebaruan tersebut memenuhi harapan dan keinginan pelanggan dalam cara yang sebelumnya tak terbayangkan.

\section{d) Inovasi kebijakan berdasarkan konsep}

Organisasi publik perlu terus melakukan perubahan paradigma, ide, gagasan sebagai bagian dari inovasi yang dilakukan berdasarkan konsep organsisasi untuk memecahkan permasalahan. Menurut kajian LAN terdapat beberapa kriteria inovasi produk yaitu :

1) Inovasi ini lahir dari perubahan cara pandang atas suatu masalah yang kemudian diwujudkan dalam kebijakan.

2) Penilaian atas kesuksesan ini dapat dilihat dengan membandingkannya dengan kebijakan sebelumnya yang dilandasi oleh cara pandang lama. Apabila hasil atau kinerja kebijakan baru lebih baik, maka inovasi konseptual dapat dipandang berhasil.

3) Biasanya, perubahan cara pandang ini dilakukan dengan melihat suatu isu dengan perspektif yang lebih positif atau dengan melakukan pembaruan paradigma.

e) Inovasi Kebijakan berdasarkan ilmu pengetahuan dan teknologi (Iptek)
Penerapan inovasi Iptek meliputi pembaharuan terhadap berbagai permasalahan yang dihadapi oleh organsisasi seperti sistem organisasi, peralatan dan skill aparatur. Hal tersebut menjadi tuntutan organsiasi dalam menghadapi perubahan dan perkembangan masyarakat yang semakin dinamis.

\section{f) Inovasi kebijakan berdasarkan struktur organisasi}

Inovasi sruktur organisasi dilakukan agar organisasi mampu fleksibel terhadap perkembangan yang terjadi dalam organisasi. Struktur organisasi yang releven dengan sifat dan perkembangan masyarakat perlu dilakukan agar organisasi mampu menciptakan kinerja aparatur semakin meningkat.

\section{g) Inovasi kebijakan berdasarkan hubungan}

Setiap organisasi, terlebih sektor publik, pasti berhubungan dengan pihak-pihak luar. Agar pencapaian tujuan dapat lebih mudah tercapai dan sumberdaya yang digunakan dapat digunakan dengan lebih cerdas dan efektif, maka organisasi perlu membina dan merangkai mekanisme hubungan dengan pihak luar dalam cara yang inovatif, saling menguntungkan, dan saling memampukan. (http:// inovasi.lan.go.id). Dengan demikian inovasi melalui hubungan yang efektif dan bersifat simbiosis mutualisme menjadi kolektifitas stakeholder dalam 
menciptakan tata kelola organisasi yang baik.

\section{h) Inovasi kebijakan pengembangan sumber daya manusia}

Secara prinsip inovasi sumber daya manusia adalah faktor yang sangat penting karena asset utama organisasi adalah manusia. Seluruh inovasi yang dilakukan tidak akan berjalan sesuai dengan yang diharapkan apabila inovasi sumber daya manusia tidak berhasil. Pentingnya organisasi dalam menyusun kebijakan internal organisasi dalam memberikan prioritas terhadap inovasi sumber daya manusia menjadi hal yang perlu dilakukan. Metode pelatihan, kompetensi, peningkatan karir dan pemberdayaan aparatur adalah beberapa metode inovasi dalam pengembangan sumber daya manusia.

\section{c. Inovasi Kebijakan Menuju terwujudnya Good Policy Governance}

Dalam upaya menuju good public policy governance, daya inovasi kebijakan dianalisis berdasarkan 4 (empat) karakteristik inovasi kebijakan sebagaimana dikemukakan oleh Freddy Navaro (2016), yaitu sebagai berikut :

1) Jenis dukungan

Good Public Policy Governance akan dicapai melalui penerapan inovasi kebijakan yang dilakukan melalui kerjasama antara pejabat pemerintah dari semua level dan tingkatan dengan aktor non pemerintah dengan tujuan untuk mencapai perubahan dalam proses organisasi dan dukungan kreatifitas.

Dalam hal ini identifikasi permasalahan kebijakan dianalisis dengan dukungan dari berbagai pihak guna memeroleh orientasi inovasi kebijakan yang berbasis pada pemecahan masalah.

2) Manajemen Inovasi

Manajemen inovasi disini dilakukan dalam bentuk penataan organisasi dan administrasi sebagai hasil dari kerjasama yang telah dilakukan dengan melibatkan sumber daya eksternal dan internal. Proses restrukturisasi tata cara penyusunan kebijakan inovatif merupakan syarat mutlak yang perlu dilakukan dalam menyusun sebuah kebijakan termasuk manajemen kelembagaan dan inovasi organisasi.

3) Jenis dan karakteristik Hubungan Inovasi kebijakan menuntut adanya karakteristik hubungan yang simbiosis mutualisme dari semua stakeholder. Melalui pendekatan hubungan demikian maka akan dapat tercapai hasil yang diharapkan. Kemampuan dalam penggunaan sumber daya secara optimal dan dukungan kerjasama yang bersifat terbuka dalam mewujudkan good public policy governance.

4) Karakteristik dalam penerapan nilai

Tingkat keberhasilan inovasi kebijakan diperoleh melalui penerapan nilai yang bermanfaat bagi kepentingan publik. Dan hal tersebut 


dilakukan dengan mendorong
kerjasama antara pemerintah,
masyarakat dan pihak swasta
dilakukan dalam upaya penguatan
sumber daya manusia di bidang
perancangan kebijakan.

\section{E. Kesimpulan}

Tata kelola kebijakan publik inovatif mensyaratkan kontribusi dalam memberikan pengetahuan-pengetahuan baru dan bermanfaat bagi kepentingan publik. Publik sebagai pemilik kepentingan dari sebuah produk kebijakan yang inovatif menginginkan output kebijakan yang dapat memberikan factor impact (faktor dampak) yang terukur dan berorientasi pada pemecahan permasalahan publik. Simpifikasi inovasi kebijakan adalah kebijakan yang mendorong dampak daya saing dan memberikan manfaat bagi kepentingan publik.

Penerapan prinsip-prinsip inovasi melalui NPS adalah reprsentasi dari penerapan inovasi kebijakan. Publik dipandang secara utuh, manusiawi dan humanis melalui pendekatan yang memberikan space kepada publik untuk berkolaborasi dan berorientasi pada peningkatan kinerja setiap elemen organisasi. Sudut pandang NPS dalam memandang inovasi kebijakan bersifat holistik dan menyeluruh serta bertujuan untuk taat terhadap kepentingan publik.
Good public policy governance akan terwujud melalui pendekatan 1)Jenis dukungan melalui penerapan inovasi kebijakan yang dilakukan melalui kerjasama antara pejabat pemerintah dari semua level dan tingkatan dengan aktor non pemerintah; 2)Manajemen Inovasi dalam bentuk penataan organisasi dan administrasi sebagai hasil dari kerjasama yang dilakukan dengan melibatkan sumber daya eksternal dan internal; 3)Jenis dan karakteristik hubungan melalui adanya karakteristik hubungan yang simbiosis mutualisme dari semua stakeholder; 4)Karakteristik dalam penerapan nilai yang diukur melalui penerapan nilai yang bermanfaat bagi kepentingan publik. Dan hal tersebut dilakukan dengan mendorong kerjasama antara pemerintah, masyarakat dan pihak swasta dilakukan dalam upaya penguatan sumber daya manusia di bidang perancangan kebijakan.

\section{Daftar Pustaka}

Batalli, Mirlinda 2011. Impact of Public Administration Innovations on Enchancing the Citizens' Expectation, International Journal of e-Education, e-Bussines, eManajemen and e-Learning, Vol 1 No 2.

Behn, Robert D. 2008. "The Adoption of Innovation: The Challenge of Learning to Adapt Tacit Knowledge", di dalam Borins, Sandford. 2008. Innovations in 
Government:
Recognition, and Rearch,
Washington, D.C:
Institution Press. Benyamin, Abdurahman 2014.

Kelemahan Regulasi dan Kebijakan Tumpulkan Pembangunan Daerah (Telaah kritis Regulasi dan Kebijakan terkait Kerjasama antar daerah di era Post Reformasi), Jurnal Pembangunan Daerah, Vol II, Edisi 2

LAN. 2016. Pengembangan Model dan Story Administrasi Negara, Pusat Intan-Dian-LAN, Jakarta.

Dwijanto et. al, 2007. Kinerja Tata Pemerintahan di Indonesia, Yogyakarta: Pusat Studi Kependudukan dan Kebijakan Universitas Gajah Mada (PSKK UGM)- Kemitraan, hlm. 10

Elanor D Glor, 2003. Applying Innovatice Proceesses to Improve Governance and Public Administration and Reduce Poverty, Innovation Journal : The Pubic Sector Innovation Journal, Volume 12(2), article 6

Hartley Jean, 2014. Innovation in Governance and Public Services : Past and Present, article in Public Money and Manajemen, The Open University (UK) Page 27-33

Mariana, Dede, 2010. Otonomi Daerah dan Inovasi Kebijakan Publik, Jurnal Governance Vol. 1 No.1

Navarro F Marinez, 2016. From Government Innovation to Public Innovation. The ICT as Key Tools,
International Journal of New Technology and Research (IJNTR), ISSN : 2454:4116., Volume 2, Issue 6, Page 4-7

Nidya S Waras, 2016. Sinergi Pemerintah Pusat dan Daerah dalam Implementasi Kebijakan ekonomi Jilid XII, Majalah Info Singkat Ekonomi dan Kebijakan Publik, Vol. VIII, No. 09.

Program for Innovation in public Administration in the Euro Meditarranaen Region - Innovmed, dilihat pada tanggal 01 Agustus 2017).http://www.unpan.org/innovm e,

Tyran, 2003. Diffusion of Policy Innovation. Universität St.Gallen. hal 5

Departement of Economic And Social Affairs, 2006. Innovation in Governance and Public Administration : Replicating what works, United Nations, New York

Widodo Tri Utomo, 2016. Inovasi sebagai keniscayaan baru dalam Ilmu dan Praktek Administrasi Publik di Indonesia, Laskar Inovasi Deputi Inovasi Administrasi Negara, Jakarta.

Wijayanti Lydia, 2012. Implementasi Kebijakan Pembangunan berkelanjutan di Kota Surakarta : Relokasi PKL di Taman Monumen Banjarsari ke Pasar Klitikan Notoharjo. Biro Penerbit Planologi Undip, Volume 8 (2) :125-137. 
Vigoda Gadot et al, 2008. Public Sector Innovation For Europe: A Multinational Eight - Country Exploration of Citizens Perspectives, Journal Public Administration, Volume 86, issue 2, page 307-329 
Spirit Publik Volume 12, Nomor 2, Oktober 2017

Halaman 14-31

P-ISSN. 1907-0489 E-ISSN 2580-3875 